\title{
Tuberkulose hos asylsøkere i statlige mottak
}

\author{
Oppfølgingen av asylsøkere med påvist latent tuberkulose er ikke god nok. Det bør opprettes et sentralt \\ register over personer med latent tuberkulose, og gis amnesti til asylsøkere med latent tuberkulose der \\ forebyggende behandling er indisert.
}

Verdens helseorganisasjon (WHO) opererer med at en tredel av verdens befolkning har latent tuberkulose (1). Det er sannsynlig at andelen vil være tilsvarende blant asylsøkere her i landet. Statistisk vil 5-10\% av personer med latent tuberkulose utvikle tuberkuløs sykdom senere i livet. Tuberkulose er høyfrekvent i fattige land og i land der helsevesenet har brutt sammen pga. langvarig krig. Asylsøkerne kommer nettopp fra slike land.

Undersøkelse for tuberkulose er lovpålagt for asylsøkere. De blir screenet i transittmottak. Asylsøkere mellom 15 år og 40 år undersøkes for tuberkulose med lungerøntgen og Mantoux'prøve (tuberkulintest). Asylsøkere over 40 år undersøkes bare med lungerøntgen, mens barn under 15 år bare undersøkes med Mantoux’ prøve.

Asylsøkere med påvist tuberkuløs lungesykdom blir holdt tilbake og behandlet i et sekundært transittmottak i eller nær Oslo. Disse får amnesti inntil behandlingen er gjennomført. Asylsøkere med normal lungerøntgen og positiv Mantoux’ prøve blir sendt til vanlige statlige asylmottak i hele landet. Der er det den kommunale helsetjenesten som har ansvaret for videre utredning og oppfølging. Harstad og medarbeidere har nylig vist $i$ en studie at det på kommunenivå er betydelig svikt i denne oppfølgingen (2).

\section{Ny tuberkuloseforskrift}

Hvordan oppfølgingen skal foregå, både på kommunenivå og i spesialisthelsetjenesten, reguleres av en forskrift hjemlet i smittevernloven. Ny tuberkuloseforskrift ble vedtatt i 2009 (3). Den nye forskriften og nye retningslinjer fra Folkehelseinstituttet har ført til endringer i oppfølgingen av latent tuberkulose.

Fra og med 2009 består oppfølging på kommunenivå av at asylsøkere under 40 år med Mantoux' prøve $\geq 10 \mathrm{~mm}$ skal få utført en blodprøve, Interferon Gamma Release Assays (IGRA-test), som er langt mer spesifikk enn Mantoux' test. Personer med positiv IGRA-test anses å ha latent tuberkulose og skal følges med videre kontroller. Ved positiv IGRA-test skal pasienten henvises til spesialisthelsetjenesten, som skal vurdere om asylsøkeren skal tilbys forebyggende behandling (et tre måneders behandlingsregime med to tuberkulostatika). Personer med spesielt kraftig utslag på Mantoux' test $(\geq 15)$ skal også henvises.
Tabeller for vurdering av behandlingsindikasjoner finnes i Folkehelseinstituttets veileder (4). I tabellene veies risiko for fremtidig utvikling av tuberkuløs sykdom mot risiko for alvorlige bivirkninger av behandling. Likevel finnes det tolkingsmuligheter ved bruk av tabellene. Folkehelseinstituttet anbefaler økt bruk av forebyggende behandling sammenliknet med det som er praksis i dag.

I ovennevnte studie fremkom det at bare $1 \%$ av asylsøkerne fikk forebyggende behandling (2). Dette er lite heldig og beror på en kombinasjon av dårlig oppfølging i kommunehelsetjenesten og vegring i spesialisthelsetjenesten. Forebyggende behandling avvises i praksis inntil oppholdstillatelse foreligger, noe som fører til at pasienten glipper i systemet.

\section{«Hos pasienter fra høyendemiske land er det viktig å tenke tuberkulose ved uklart sykdomsbilde»}

Når man diagnostiserer tuberkuløs sykdom, eller når man beslutter å gjennomføre forebyggende behandling, blir behandlingen koordinert og overvåket av en tuberkulosekoordinator ved sykehuset. Spesialistlege (lungelege, infeksjonslege eller pediater) har det medisinske ansvaret. Den praktiske gjennomføringen utenfor sykehus ivaretas $\mathrm{i}$ hovedsak av kommunal hjemmetjeneste.

\section{Oppfølging av asylsøkere i praksis}

Vestfold Migrasjonshelsesenter (Migrasjonshelsesenteret) er et interkommunalt helsetjenestetilbud til beboere ved to statlige asylmottak, med til sammen 400 plasser, og til nyankomne bosatte flyktninger og familiegjenforente i de fire samarbeidskommunene. Migrasjonshelsesenterets målsetting er å ivareta fastlegefunksjon for gruppen, ivareta smittevernfunksjoner $\mathrm{i}$ henhold til forskrifter og retningslinjer og å gi best mulig støtte ved psykiske problemer.

Ved senteret er det to fastleger, begge i $50 \%$ stilling. For å ivareta smittevernarbeidet er det ansatt en helsesøster på deltid. Det er etablert gode rutiner for oppfølging av pasienter med latent tuberkulose. Likevel forekommer det overraskelser og tilfeller der overgang fra latent til aktiv tuberkulose oppdages i seneste laget. Ved retrospektiv gjennomgang ser man hvilke signaler man burde reagert raskere på. Vi har for eksempel sett flere tilfeller der diagnosen er blitt forsinket fordi man ikke aktivt har spurt om hoste og vekttap.

Vi har også erfart at man ikke bør slå seg til ro med opplysninger om at pasienten har fått behandling for tuberkulose før ankomst. Behandlingen kan ha vært ufullstendig slik at tuberkulosen dukker opp igjen. Da er risikoen for multiresistens til stede. Følgende kasuistikk illustrerer hvordan forsinket oppfølging kan få alvorlige konsekvenser:

Tre måneder etter ankomst til Norge oppsøkte en ung kvinne fastlegen på grunn av smerter høyt oppe i ryggen. Det ble tatt et røntgenbilde som viste kileform av Th 2. Innen man rakk å innkalle pasienten for oppfølging, utviklet pasienten plutselig pareser $i$ underekstremitetene. Hun ble, via legevakt, innlagt på sykehusets nevrologiske avdeling. Etter MR-undersøkelse ble det konkludert med «tumor» i columna. Pasienten ble overført til universitetssykehus og operert ved nevrokirurgisk avdeling. Under operasjonen ble det tatt biopsi til utredning for tuberkulose, mikroskopi og dyrking. Det viste seg at hun hadde tuberkuløs spondylitt med tverrsnittslesjon som følge av fullstendig destruert Th 2. Postoperativt ble pasienten behandlet ved rehabiliteringsavdeling hvor hun gjorde gode fremskritt med hensyn til gangfunksjon. Etter noen uker kom det beskjed fra universitetssykehuset om at dyrking og resistensbestemmelse viste multiresistent tuberkulose. Pasienten ble så behandlet med 2. linje-medikamenter i 1 1/2 år. Det endte godt. Tuberkulosen ble sanert, og pasienten fikk tilbake tilnærmet normal gangfunksjon.

Av kasuistikken kan vi trekke følgende lærdom: Hos pasienter fra høyendemiske land er det viktig å tenke tuberkulose ved uklart sykdomsbilde og å tenke tuberkuløs spondylitt ved smerter i torakalområdet eller i torakolumbalovergangen. 


\section{Hva bør gjøres?}

Betydelig forsinkelse i diagnostikken, som i eksemplet over, bør ikke forekomme i vår del av verden. Dessverre er det ikke uvanlig. Hvorfor? Alle med latent tuberkulose (positiv IGRA-test) skal henvises til spesialisthelsetjenesten. I praksis ser vi at voksne, friske asylsøkere får avslag på henvisningen. Unntaket er der det er komorbiditet med hiv eller funn på lungerøntgen. I avslagsbrevet står det ofte at vedkommende kan henvises på nytt hvis han/hun får innvilget opphold i Norge. Her er det rom for svikt. Trolig blir muligheten for forebyggende behandling, etter innvilget opphold og bosetting i Norge, ikke brukt. Pasienten flytter til ny kommune og blir tildelt en fastlege.

De færreste fastlegene tenker på å sjekke om det er noe ugjort med hensyn til tuberkuloseoppfølgingen. Dermed kan bosatte asylsøkere bli gående lenge med sykdommen før den diagnostiseres. Selv om fastlegen tenker på tuberkulose, vil det være tidkrevende å finne frem til de undersøkelsene som er gjort, spesielt fordi asylsøkere ofte flytter mellom mottak eller fordi de blir bosatt i en annen kommune når de får opphold.

Opplysninger om positive tuberkulosefunn skal sendes til kommuneoverlegen (eller smittevernansvarlig) i tilflyttingskommunen, men dette svikter ofte, og informasjonen når sjelden frem til pasientens fastlege. Slik informasjon er i praksis vanskelig tilgjengelig for fastlegene. Vi mener derfor at to tiltak bør iverksettes.

Det bør opprettes et sentralt register, noe i likhet med Nasjonalt vaksinasjonsregister (SYSVAK), hvor personer med latent tuber- kulose registreres. Dette registeret må være lett tilgjengelig for fastlegene via Norsk helsenett.

Hvis det finnes indikasjon for forebyggende behandling, bør asylsøkere med latent tuberkulose behandles og gis amnesti $\mathrm{i}$ behandlingsperioden.

Da nesten halvparten av asylsøkerne får opphold i Norge, ville utvidet bruk av forebyggende behandling merkbart ha redusert antallet nye tuberkulosetilfeller i Norge. Fra en humanitær synsvinkel er det bra at også de som må forlate landet, reiser uten latent tuberkulose. Siden noen personer med avslag på asylsøknad velger å leve i skjul i Norge, kan forsømmelse av forebyggende behandling for denne gruppen også få konsekvenser her hjemme.

\section{Reidun Brunvatne}

rbrunvat@online.no

Stokke

\section{Mona Strand Jenssen}

Rafid Al-Ani

Vestfold MigrasjonshelsesenterTønsberg

\section{Elda Furulund Borg}

Lungeavdelingen

Sykehuset i Vestfold

Tønsberg

Pasienten har gitt samtykke til at artikkelen blir publisert.

Reidun Brunvatne (f. 1938) er pensjonert fastlege ved Vestfold Migrasjonshelsesenter. Oppgitte interessekonflikter: Mottok vanlig lønn for klinisk arbeid ved Vestfold Migrasjonshelsesenter.
Mona Strand Jenssen (f. 1954) er helsesøster ved Vestfold Migrasjonshelsesenter. Oppgitte interessekonflikter: Mottar vanlig lønn for klinisk arbeid ved Vestfold Migrasjonshelsesenter.

Rafid Al-Ani (f. 1971) er fastlege ved Vestfold Migrasjonshelsesenter.

Oppgitte interessekonflikter: Mottar vanlig lønn for klinisk arbeid ved Vestfold Migrasjonshelsesenter.

Elda Furulund Borg (f. 1955) er tuberkulosekoordinator i Vestfold

Ingen oppgitte interessekonflikter.

\section{Litteratur}

1 Verdens helseorganisasjon. http://who.int/ mediacentre/factsheets/fs104/en/ (24.11.2011).

2. Harstad I, Heldal E, Steinshamn SL et al. Screening and treatment of latent tuberculosis in a cohort of asylum seekers in Norway. Scand J Public Health, 2010; 38: 275-282.

3. Forskrift om tuberkulosekontroll. http://lovdata.no/ cgi-wift/wiftldles?doc=/app/gratis/www/docroot/ for/sf/ho/to-20090213-0205-

006.html\&emne=tuberkuloseforskrift*\&\& (24.11.2011)

4. Nasjonalt folkehelseinstitutt. Tuberkuloseveilederen. Oslo: Nasjonalt folkehelseinstitutt, 2010.

Mottatt 20.6. 2011, første revisjon innsendt 1.9. 2011, godkjent 29.9. 2011. Medisinsk redaktør Anne Kveim Lie. 